\title{
Variation and relationships of morphological traits, shoot yields and essential oil contents of four Anthemis species
}

\author{
Mohammad Ali Alizadeh*, Ali Ashraf Jafari \\ Research Institute of Forests and Rangelands (Agricultural Research Education and Extension Organization) \\ P.O. Box 13185-116, Tehran, Iran
}

\begin{abstract}
Anthemis L. is a genus of aromatic flowering plants in the family Asteraceae and is native to Iran. In this research, 62 accessions of four chamomile species including Anthemis tinctoria, A. triumfetti, A. haussknechtii and $A$. pseudocotula were evaluated for morphological traits. Four experiments were conducted using a randomized complete block design with three replications at the Research Institute of Forest and Rangeland, Tehran, Iran in 2011. Data were collected for the morphological traits for all of the species and essential oil content for A. triumfetti and A. pseudocotula. The results showed that plant height was positively correlated with canopy area for all of the species except $A$. triumfetti $(p<0.01)$. There were positive correlations between flower number with plant height and canopy area in both A. tinctoria and A. haussknechtii $(p<0.01)$. Fresh and dry weight were positively correlated with canopy area and plant height in all of the species $(p<0.01)$, except $A$. tinctoria for canopy area and $A$. triumfetti for plant height. GDD had a positive correlation with canopy area for $A$. triumfetti $(p<0.05)$. There was a positive correlation between essential oil yield and plant height, fresh and dry weight in A. triumfetti and A. pseudocotula $(p<0.05)$. Using cluster analysis (Ward method), the accessions of A. triumfetti, A. tinctoria, A. haussknechtii and A. pseudocotula were grouped into $3,2,4$ and 2 clusters, respectively. The results of cluster analysis separated the accession based on shoot yield, morphological traits and maturity. In some items, the accessions within each cluster were coordinated with their geographical provenance.
\end{abstract}

Key words: Anthemis, Asteraceae, chamomile, cluster analysis, correlation

\section{INTRODUCTION}

Anthemis is a genus of aromatic flowering plants in the family Asteraceae. Anthemis species are native to the Mediterranean area, southwest Asia and Iran (Zargari 2008). The species of the Anthemis genus are widely used in pharmaceutics, cosmetics and food craft. The flowers of the genus have welldocumented uses as disinfectants and healing herbs, the main components being natural flavonoids and essential oils (Uzel et al. 2004).
A. pseudocotula Boiss. (Tab. 1) is an annual and aromatic ornamental plant that grows natively in the northwest, west and southwest regions of Iran. Its wild types are used for medicinal purposes for gout, headache, carminative, indigestion, neuralgia, skin irritations, catarrhal, deodorant and as a sedative (Oberprieler and Vogt 1999).

A. haussknechtii Boiss. \& Reut. (Tab. 1) grow in Iran, Iraq and Syria. Its flowering and fruiting is from May to June in Iran (Mozaffarian 2008).

\footnotetext{
*Corresponding author.

Tel.: +98 9122876952 ;

e-mail: alizadeh202003@gmail.com (M.A. Alizadeh).
} 
Table 1. Species, accessions number, growth type and accession eluviation range above sea level

\begin{tabular}{lccc}
\hline Name of species & Accession No. & Growth type & Eluviation range \\
\hline A. tinctoria & 18 & Perennial & 1211 to $1969 \mathrm{~m}$ \\
A. triumfetti & 13 & Perennial & 1368 to $2390 \mathrm{~m}$ \\
A. haussknechtii & 21 & Annual & 1120 to $2400 \mathrm{~m}$ \\
A. pseudocotula & 10 & Annual & 587 to $2300 \mathrm{~m}$ \\
\hline
\end{tabular}

The A. tinctoria L. (Tab. 1) species is a biennial plant and used as a popular medical plant. It has a cathartic effect due to its bitter fruit oil. The species grows in rocky slopes in the wild with more sunshine, especially on limestone. This species grows in regions in the north, western north, west and central of Iran (Mozaffarian 2008, Zargari 2008).

A. triumfetti (L.) (Tab. 1) DC is found in Europe, Iran and the Caucasus Mountains. Its flowering and maturity stages are in late spring and late summer, respectively (Mozaffarian 2008).

All of the species grow naturally in rangelands. However, in recent years, farmer have begun small scale cultivation in the provinces. The main aim of this study is the domestication and cultivation of medicinal plants such as Anthemis.

In medicinal plant breeding programs, finding populations with both high aerial shoots and essential oil content is a very attractive objective. It is necessary to identify some of the related traits that have a positive correlation with shoot and essential oil yield. This finding would be useful for the collection of desirable genes for conducting breeding methods of new varieties. Successful selection of plant breeding and genetic recombination depends on diversity through heterosis (Humphreys 1991). Consequently, this study of the potential for improvement in essential oils should be combined with an analysis of yield and its interrelationship with other morphological plants.

The extent to which various characteristics are correlated in shoot yield and essential oil yield has been studied by a number of researchers. Dadkhah et al. (2009) in Matricaria chamomilla L. found a positive correlation between flower number and shoot weight. Adeli et al. (2015) found positive correlations between vegetative traits and shoot yield in A. triumfetti. Alizadeh et al. (2015) found positive relationships between essential oil $\%$ and GDD for Anthemis triumfetti L. Klimko et al. (2006) evaluated properties of the stems, flowers and fruit of yellow chamomile of $A$. tinctoria in Poland.
In addition, the assessment of the divergence of genetic materials is also vital to the success of gene recombination that is designed to be exploited. Strong positive relationships have been found between genetic distance and heterosis in a broad range of crop species (Humphreys 1991). Therefore, the measure of genetic distance should have more value to breeding when based on a broad range of traits relevant to breeding objectives.

Despite the unique role of different species of Anthemis in the production of pharmaceutical species, unfortunately little information on the genetic diversity among the Anthemis species exists for shoot and essential oil yield here in Iran. The objectives of the study were: to examine the relationships among shoot yield, morphological traits and essential oil \% in the four species of Anthemis and to determine the pattern of genetic variation and genotype groups using cluster analysis on the basis of morphological traits to identify groups of accessions through a multivariate approach.

\section{MATERIAL AND METHODS}

In this research 62 accessions of four chamomile species including $A$. tinctoria, A. triumfetti, A. haussknechtii and A. pseudocotula were provided from the Natural Resource Gene Bank of the Research Institute of Forest and Rangelands, Tehran, Iran. The seeds were sown in Jiffy pots in November 2010. Then, the seedlings were transferred to the field in the Alborz Research Station in Karaj, Iran in March 2011. Four experiments were conducted using the Randomized Complete Block Design (RCBD) with three replications. Each experiment unit consisted of three $4 \mathrm{~m}$ rows $50 \mathrm{~cm}$ apart from each other with a $50 \mathrm{~cm}$ distance of spaced plants $(30$ plants per plot).

In this research, data were collected from 10 plant per replication in the middle row for morphological traits including: canopy diameter, plant height, number of flowers, flowering and maturity dates, fresh and dry shoot weight and 
growth degree days (GDD) for all species, while essential oil percentage and essential oil yield were recorded for A. triumfetti and A. pseudocotula.

For GDD, flowering dates were recorded as the number of days from 21 March until first flower emergence per plant. GDD were recorded by Frank et al. (1993) as follows:

$$
\mathrm{GDD}=\frac{\mathrm{T}_{\min }+\mathrm{T}_{\max }}{2}-\mathrm{T}_{\mathrm{b}}
$$

where: $\mathrm{GDD}=$ growth degree days, $\mathrm{T}_{\max }=$ maximum daily temperature, $\mathrm{T}_{\min }=$ minimum daily temperature, $\mathrm{T}_{\mathrm{b}}=$ the base temperature (physiological zero for germination). The source of metrological data was collected from (IRMO 2011).

For essential oil extraction, the shoot samples of plants were collected in the fully flowering stage, then $80 \mathrm{~g}$ were taken for measuring essential oil using a Kelvenger Instrument on the base of Hungarian plant pharmacopeia letter (Siddiqui et al. 2006) as follows:

Essential oil content $\%=\frac{\text { Essential oil weight } g}{\text { Shoot dry matter } g} \times 100$

Yield of essential oil was calculated by Essential oil $\% \times$ Shoot dry weight (g) per plant.

Table 2. Correlation coefficients of morphological traits, shoot yield and growth degree days in four chamomile (Anthemis) species

\begin{tabular}{|c|c|c|c|c|c|c|c|c|}
\hline Traits & Species & $\begin{array}{l}\text { Canopy } \\
\text { area } \\
\left(\mathrm{cm}^{2}\right)\end{array}$ & $\begin{array}{l}\text { Plant } \\
\text { height } \\
(\mathrm{cm})\end{array}$ & $\begin{array}{l}\text { Flower } \\
\text { number }\end{array}$ & $\begin{array}{c}\text { Fresh } \\
\text { weight } \\
\left(\text { g plant }^{-1}\right)\end{array}$ & $\begin{array}{c}\text { Dry } \\
\text { weight } \\
\left(\text { g plant }^{-1}\right)\end{array}$ & $\begin{array}{c}\text { Growth } \\
\text { degree } \\
\text { days }\left({ }^{\circ} \mathrm{C}\right)\end{array}$ & $\begin{array}{c}\text { Essential } \\
\text { oil }(\%)\end{array}$ \\
\hline \multirow[t]{4}{*}{ Plant height } & A. tinctoria & $0.64^{* *}$ & & & & & & \\
\hline & A. triumfetti & 0.35 & & & & & & \\
\hline & A. haussknechtii & $0.93^{* *}$ & & & & & & \\
\hline & A. pseudocotula & $0.95^{* *}$ & & & & & & \\
\hline \multirow[t]{4}{*}{ Flower number } & A. tinctoria & $0.86^{* *}$ & $0.75^{* *}$ & & & & & \\
\hline & A. triumfetti & $0.64^{*}$ & 0.40 & & & & & \\
\hline & A. haussknechtii & $0.86^{* *}$ & $0.81^{* *}$ & & & & & \\
\hline & A. pseudocotula & 0.17 & 0.21 & & & & & \\
\hline \multirow[t]{4}{*}{ Fresh weight } & A. tinctoria & 0.27 & $0.58^{* *}$ & 0.38 & & & & \\
\hline & A. triumfetti & $0.73^{* *}$ & 0.07 & $0.58^{*}$ & & & & \\
\hline & A. haussknechtii & $0.93^{* *}$ & $0.83^{* *}$ & $0.71^{* *}$ & & & & \\
\hline & A. pseudocotula & $0.88^{* *}$ & $0.83^{* *}$ & 0.13 & & & & \\
\hline \multirow[t]{4}{*}{ Dry weight } & A. tinctoria & 0.28 & $0.63^{*}$ & 0.37 & $0.96^{* *}$ & & & \\
\hline & A. triumfetti & $0.82^{* *}$ & 0.05 & 0.35 & $0.90^{* *}$ & & & \\
\hline & A. haussknechtii & $0.91^{* *}$ & $0.81^{* *}$ & $0.64^{* *}$ & $0.99^{* *}$ & & & \\
\hline & A. pseudocotula & $0.78^{* *}$ & $0.80^{* *}$ & 0.11 & $0.93^{* *}$ & & & \\
\hline \multirow[t]{4}{*}{ Growth degree days } & A. tinctoria & -0.14 & 0.18 & -0.10 & 0.03 & 0.06 & & \\
\hline & A. triumfetti & $0.55^{*}$ & -0.23 & 0.03 & 0.21 & 0.44 & & \\
\hline & A. haussknechtii & -0.01 & 0.01 & -0.13 & 0.07 & 0.11 & & \\
\hline & A. pseudocotula & 0.27 & 0.18 & 0.01 & 0.28 & 0.21 & & \\
\hline \multirow[t]{2}{*}{ Essential oil \% } & A. triumfetti & 0.12 & 0.44 & -0.07 & 0.03 & 0.07 & -0.12 & \\
\hline & A. pseudocotula & -0.11 & 0.04 & -0.14 & 0.13 & 0.20 & -0.21 & \\
\hline \multirow[t]{2}{*}{ Essential oil yield } & A. triumfetti & $0.57^{*}$ & $0.49^{*}$ & 0.19 & 0.46 & $0.55^{*}$ & -0.03 & $0.57^{*}$ \\
\hline & A. pseudocotula & 0.35 & $0.52^{*}$ & -0.02 & $0.53^{*}$ & $0.66^{*}$ & -0.07 & 0.35 \\
\hline
\end{tabular}

*Values marked with an asterisk are significant at $p=0.05(*)$ or $p=0.01(* *)$ 
The collected data were analysed and phenotypic correlation between traits were determined for each species (experiments). Cluster analysis was carried out using the Ward method (Ward 1963). All statistical analyses were conducted using MINITAB 16 software.

\section{RESULTS}

\section{Correlation between traits}

The results of correlation analysis for each species of A. triumfetti, A. tinctoria, A. haussknechtii and A. pseudocotula are presented in Table 2. The results showed that plant height was positively correlated with canopy area for all of the species except $A$. triumfetti $(p<0.01)$. There were positive correlations between flower number with plant height and canopy area in both A. tinctoria and A. haussknechtii $(p<0.01)$. The correlations of fresh and dry weight were similar with the other traits. Both traits were positively correlated with canopy area and plant height in all of the species $(p<0.01)$, except A. tinctoria for canopy area and $A$. triumfetti for plant height. Both traits also had a positive correlation with flower number in A. haussknechtii $(p<0.01)$. GDD had a positive correlation with canopy area for $A$. triumfetti $(p<0.05)$. There were positive correlations between essential oil yield with plant height, fresh and dry weight in A. triumfetti and A. pseudocotula ( $p<$ 0.05 ). In addition, essential oil yield was positively correlated with canopy area and essential oil percentage for $A$. triumfetti $(p<0.05)$.

\section{Cluster analysis}

Cluster analysis of the accessions for A. tinctoria showed that the accessions were divided into two groups according to genetic distance (11.04). The first and second cluster had 6 and 12 accessions, respectively (Fig. 1). Analysis of variance between clusters showed that the accessions in cluster 1 had higher mean values than cluster 2 for morphological traits. There was no difference between clusters for GDD (Tab. 3).

According to the dendrogram (Fig. 2), accessions of $A$. triumfetii were grouped into three clusters with genetic distance (7.2). The first, second and third clusters had 2, 6 and 5 accessions, respectively (Fig. 2). The accessions of Golastan (10695) and Semnan (21609) were placed in the first cluster. This cluster had higher values of canopy area, flower number and GDD, indicating a valuable source of genetic resources for the domestication of this species (Tab. 4). Lower values of all of the traits were obtained in cluster 2 . There was no differences for shoot yield and plant height between clusters 2 and 3 (Tab. 4).

Based on cluster analysis, the accessions of A. haussknechtii were grouped into four clusters with genetic distance of 12.65 . The first, second, third and forth clusters had 6,1,11 and 2 accessions, respectively (Fig. 3). Mean comparison between

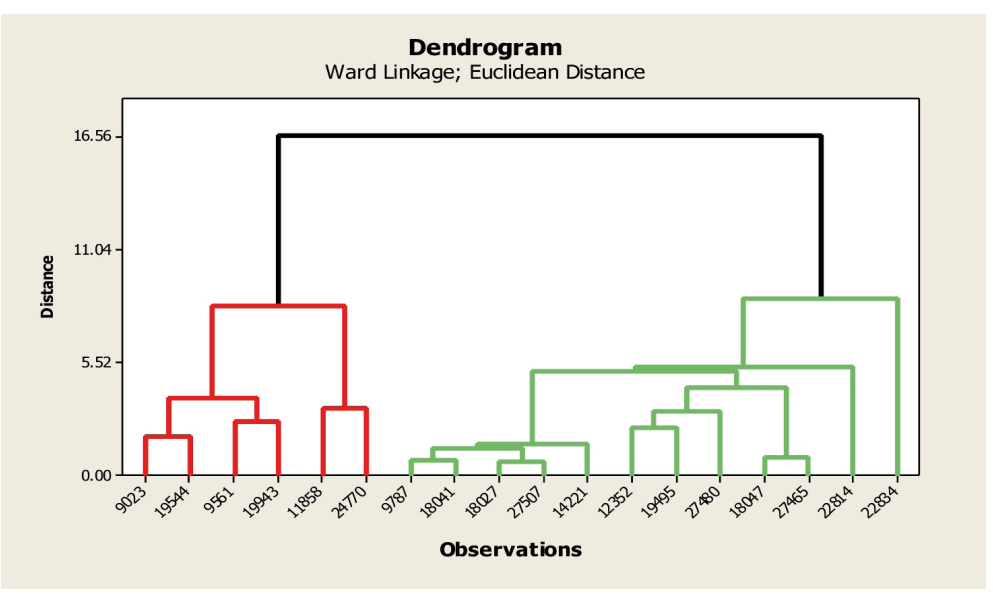

Figure 1. Dendrogram of the $18 \mathrm{~A}$. tinctoria accessions based on morphological traits

Table 3. Mean comparison of the morphological traits of two clusters of A. tinctoria

\begin{tabular}{lcccccc}
\hline Cluster number & $\begin{array}{c}\text { Canopy area } \\
\left(\mathrm{cm}^{2}\right)\end{array}$ & $\begin{array}{c}\text { Plant height } \\
(\mathrm{cm})\end{array}$ & $\begin{array}{c}\text { Number of } \\
\text { flowers }\end{array}$ & $\begin{array}{c}\text { Fresh weight } \\
(\mathrm{g} \text { per plant })\end{array}$ & $\begin{array}{c}\text { Dry weight } \\
(\mathrm{g} \text { per plant })\end{array}$ & $\begin{array}{c}\text { Growth degree } \\
\text { days }\left({ }^{\circ} \mathrm{C}\right)\end{array}$ \\
\hline 1 & $1993 \mathrm{a}^{*}$ & $44.98 \mathrm{a}$ & $68.14 \mathrm{a}$ & $138.56 \mathrm{a}$ & $43.08 \mathrm{a}$ & $1739 \mathrm{a}$ \\
2 & $971 \mathrm{~b}$ & $32.16 \mathrm{~b}$ & $22.83 \mathrm{~b}$ & $91.93 \mathrm{~b}$ & $28.77 \mathrm{~b}$ & $1818 \mathrm{a}$ \\
\hline
\end{tabular}

*Values in columns marked with the same letter do not differ significantly at $p=0.05$ 


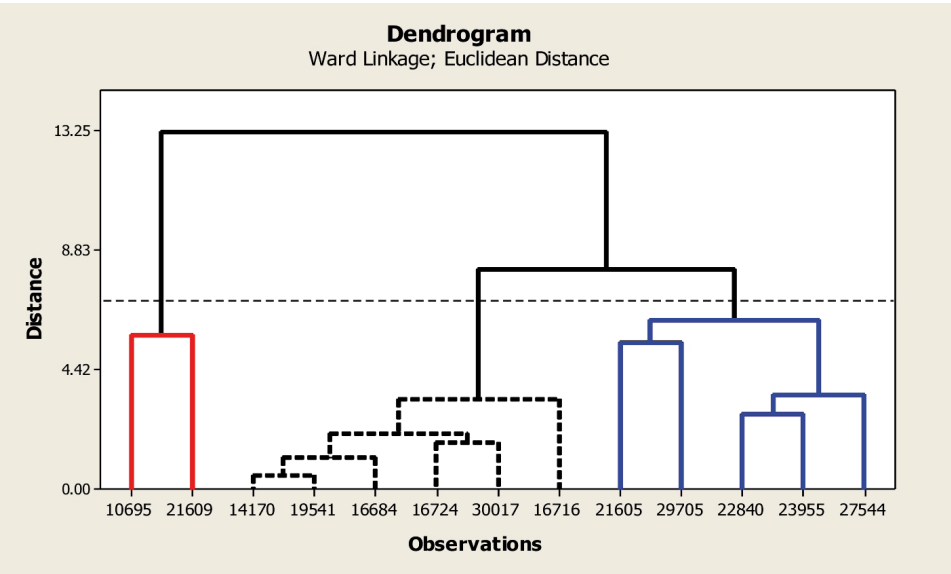

Figure 2. Dendrogram of the $13 \mathrm{~A}$. triumfetti accessions based on morphological traits

Table 4. Mean comparison of the morphological traits of two clusters of A. triumfetti

\begin{tabular}{lcccccc}
\hline Cluster number & $\begin{array}{c}\text { Canopy area } \\
\left(\mathrm{cm}^{2}\right)\end{array}$ & $\begin{array}{c}\text { Plant height } \\
(\mathrm{cm})\end{array}$ & $\begin{array}{c}\text { Number of } \\
\text { flowers }\end{array}$ & $\begin{array}{c}\text { Fresh weight } \\
(\mathrm{g} \text { per plant })\end{array}$ & $\begin{array}{c}\text { Dry weight } \\
(\mathrm{g} \text { per plant })\end{array}$ & $\begin{array}{c}\text { Growth degree } \\
\text { days }\left({ }^{\circ} \mathrm{C}\right)\end{array}$ \\
\hline 1 & $3877 \mathrm{a}^{*}$ & $39.70 \mathrm{a}$ & $104.3 \mathrm{a}$ & $326.3 \mathrm{a}$ & $138.33 \mathrm{a}$ & $3048 \mathrm{a}$ \\
2 & $1027 \mathrm{~b}$ & $31.53 \mathrm{a}$ & $18.44 \mathrm{~b}$ & $131.8 \mathrm{~b}$ & $41.16 \mathrm{~b}$ & $1785 \mathrm{~b}$ \\
3 & $1578 \mathrm{~b}$ & $38.52 \mathrm{a}$ & $55.38 \mathrm{~b}$ & $241.7 \mathrm{ab}$ & $68.36 \mathrm{ab}$ & $1626 \mathrm{~b}$ \\
\hline
\end{tabular}

*Explanations: see Table 3

clusters showed that the accessions of cluster 3 had higher values for all of the traits than the other clusters. The accessions in cluster 1, which had lower GDD coupled with moderate shoot yield, could be considered for cultivation in a dry land farming system. The accessions of cluster 4 with higher flower numbers were classified as a valuable genetic resource for breeding improved new varieties (Tab. 5).

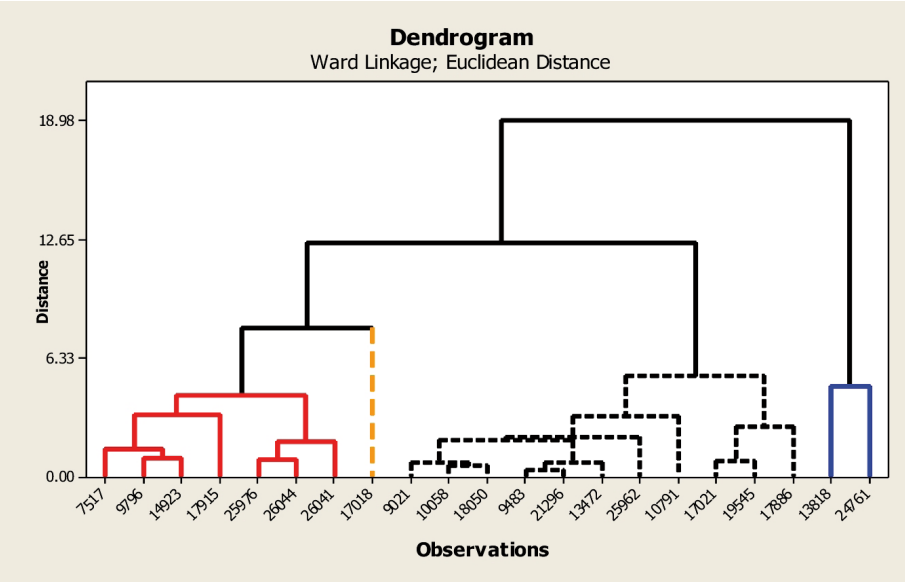

Figure 3. Dendrogram of the 21 A. haussknechtii accessions based on morphological traits

Table 5. Mean comparison of the morphological traits of four clusters of A. haussknechtii

\begin{tabular}{lcccccc}
\hline $\begin{array}{l}\text { Number of } \\
\text { cluster }\end{array}$ & $\begin{array}{c}\text { Canopy area } \\
\left(\mathrm{cm}^{2}\right)\end{array}$ & $\begin{array}{c}\text { Plant height } \\
(\mathrm{cm})\end{array}$ & $\begin{array}{c}\text { Number of } \\
\text { flower }\end{array}$ & $\begin{array}{c}\text { Fresh weight } \\
(\mathrm{g} \text { per plant })\end{array}$ & $\begin{array}{c}\text { Dry weight } \\
(\mathrm{g} \text { per plant })\end{array}$ & $\begin{array}{c}\text { Growth degree } \\
\text { days }\left({ }^{\circ} \mathrm{C}\right)\end{array}$ \\
\hline 1 & $559 \mathrm{~b}^{*}$ & $15.39 \mathrm{~b}$ & $56.27 \mathrm{~b}$ & $80.4 \mathrm{~b}$ & $23.03 \mathrm{~b}$ & $721 \mathrm{~b}$ \\
2 & $309 \mathrm{c}$ & $12.03 \mathrm{c}$ & $28.95 \mathrm{c}$ & $43.0 \mathrm{~b}$ & $10.33 \mathrm{~b}$ & $987 \mathrm{ab}$ \\
3 & $1398 \mathrm{a}$ & $27.37 \mathrm{a}$ & $81.04 \mathrm{ab}$ & $317.7 \mathrm{a}$ & $130.15 \mathrm{a}$ & $1015 \mathrm{a}$ \\
4 & $830 \mathrm{ab}$ & $21.25 \mathrm{ab}$ & $93.28 \mathrm{a}$ & $77.3 \mathrm{~b}$ & $18.30 \mathrm{~b}$ & $1073 \mathrm{a}$ \\
\hline
\end{tabular}

*Explanations: see Table 3 


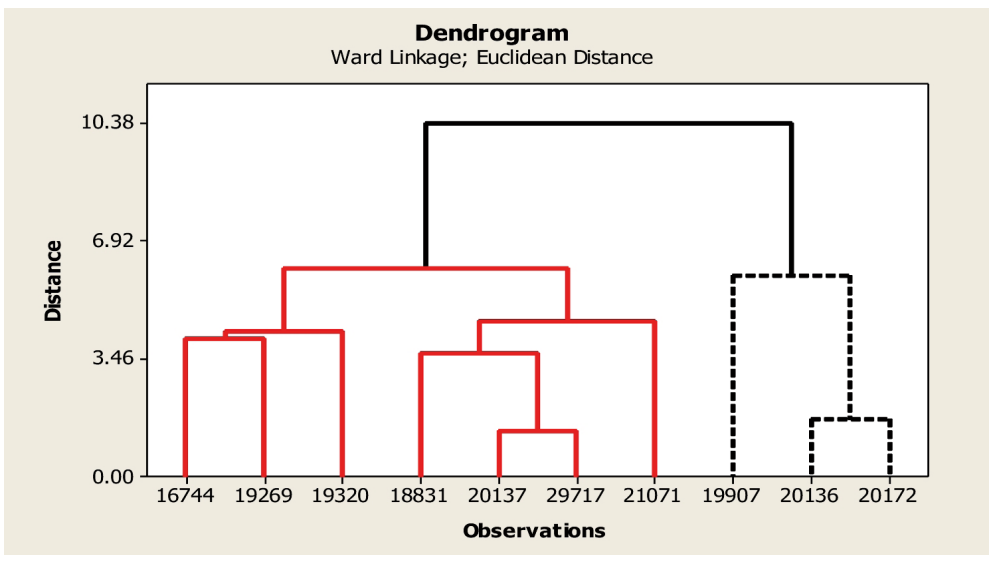

Figure 4. Dendrogram of the $10 \mathrm{~A}$. pseudocotula accessions based on morphological traits

Table 6. Mean comparison of the morphological traits of four clusters of $A$. pseudocotula

\begin{tabular}{lcccccc}
\hline Cluster number & $\begin{array}{c}\text { Canopy area } \\
\left(\mathrm{cm}^{2}\right)\end{array}$ & $\begin{array}{c}\text { Plant height } \\
(\mathrm{cm})\end{array}$ & $\begin{array}{c}\text { Number of } \\
\text { flowers }\end{array}$ & $\begin{array}{c}\text { Fresh weight } \\
(\mathrm{g} \text { per plant })\end{array}$ & $\begin{array}{c}\text { Dry weight } \\
(\mathrm{g} \text { per plant })\end{array}$ & $\begin{array}{c}\text { Growth degree } \\
\text { days }\left({ }^{\circ} \mathrm{C}\right)\end{array}$ \\
\hline 1 & $1740 \mathrm{~b}^{*}$ & $37.59 \mathrm{~b}$ & $142.53 \mathrm{~b}$ & $235.6 \mathrm{~b}$ & $54.72 \mathrm{~b}$ & $1309 \mathrm{a}$ \\
2 & $2976 \mathrm{a}$ & $52.87 \mathrm{a}$ & $157.03 \mathrm{a}$ & $394.8 \mathrm{a}$ & $92.10 \mathrm{a}$ & $1358 \mathrm{a}$ \\
\hline
\end{tabular}

*Explanations: see Table 3

The accessions of $A$. pseudocotula were grouped into two clusters (Fig. 4). The first and second clusters had 7 and 3 accessions, respectively. Mean comparison between the two clusters showed that the accessions of cluster 2 had higher values of all of the traits except GDD than cluster 1 (Tab. 6).

\section{DISCUSSION}

The correlation between traits for all of the species showed that there were positive correlations between most traits. Results from A. triumfetti showed that by increasing the vegetative duration and flowering period, flower yield components would increase and finally shoot fresh and dry weight would increase. This result was similar to result of Solouki et al. (2008) in Matricaria chamomilla.

There were no relationships between GDD and all of the traits of $A$. tinctoria, A. haussknechtii and A. pseudocotula. Pirkhezri et al. (2010) found a negative correlation between phenological and morphological traits such as flower number, shoot yield and plant height in Matricaria chamomilla $\mathrm{L}$. In contrast, Adeli et al. (2013) showed that essential oil $\%$ had a positive correlation with GDD in two species, Matricaria recutita and M. aurea.

There was a positive correlation between essential oil yield and plant height, fresh and dry weight in A. triumfetti and A. pseudocotula $(p<0.05)$. In addition, essential oil yield was positively correlated with canopy area and essential oil percentage for A. triumfetti $(p<0.05)$. This phenomenon showed that essential oil yield is high when the shoot fresh and dry weight and essential oil $\%$ increased. This result is in agreement with Hamisy et al. (2012) in Tanacetum parthenium and Pirkhezri et al. (2010) in Matricaria chamomilla, who found a positive correlation between essential oil \%, flower number and shoot fresh yield. Both essential oil yield and essential oil \% are affected by environmental factors such as plant density, date of cultivation, temperature, light and fertilization (Golparvar and Ghasemi-Pirbalouti 2011). In our study, there was no correlation between essential oil \% and all of the traits in $A$. triumfetti and A. pseudocotula. This is in agreement with Golparvar and Ghasemi-Pirbalouti (2011) in Matricaria chamomilla. This result confirmed that the cultivars with high shoot yield had constant essential oil \%, which produced more essential oil yield.

There were no correlations between flower number and other economically important traits such as plant height and shoot yield in A. pseudocotula. This result is in agreement with Salamon (1992), who reported that plant height and plant size had no effect in the flower production of chamomile.

According to cluster analysis of A. triumfetii, the first cluster had higher values of canopy area, flower number and GDD, indicating a valuable source of genetic resources for the domestication of this species. This result was in agreement with 
Singh (1982), who reported wide genetic variation for the Matricaria chamomilla germplasm. The results of cluster analysis separated accession based on shoot yield, morphological traits and maturity. In some items, the accessions within each cluster were coordinated with their geographical provenance.

\section{CONCLUSIONS}

1. This result showed that by increasing vegetative duration and flowering period in A. triumfetti, flower yield components would increase and therefore shoot fresh and dry weight would increase as well.

2. Regarding cluster analysis, cluster one of A. tinctoria and A. triumfetti, cluster three of A. haussknechtii and cluster two of A. pseudocotula had higher values for all traits.

3. In A. triumfetti and A. pseudocotula, the essential oil yield was positively correlated with canopy area plant height and shoot fresh and dry weight.

\section{ACKNOWLEDGEMENT}

We would like to thank the director and researcher deputy of the Research Institute of Forest and Rangeland in Iran for their financial support of this research study and my colleagues in the Natural Gene Bank Department.

\section{FUNDING}

This research work was supported by funding by the Research Institute of Forest and Rangeland (Agricultural Research Education and Extension Organization) in Tehran, Iran.

\section{AUTHOR CONTRIBUTIONS}

This research paper was exploited from the comprehensive research title: "Identification and evaluation of genetic resources of Anthemis, Matricaria and Tanacetum in the Natural Resources Gene Bank, Iran". In this research, M.A.A. - was the first and corresponding author of the paper and the leader of the research project and A.A.J. - was the co-author of the paper and researcher of the research project; the main sections of the article were written by M.A.A. - as the first and corresponding author; analysis of data of this research article was carried out by A.A.J. - as the co-author of the paper.

\section{CONFLICT OF INTEREST}

Authors declare no conflict of interest.

\section{REFERENCES}

Adeli N., Alizadeh M.A., Mohammai A., Jafari A.A., 2015. Evaluation of morphological, phenological traits and essential oil yield of the populations of some Chamomile populations of Anthemis haussknechtii species. Agron. J. (Pajohesh \& Sazandeghi) 28: $185-$ 192.

Adeli N., Alizadeh M.A., Jafari A.A., 2013. Evaluation of essential oil yield, morphological and phenological traits in some populations of two Chamomile species (Matricaria recutita and $M$. aurea). J. Med. Plants By-products 2(2): 153-158.

Alizadeh M.A., Adeli N., Jafari A.A., 2015. Variation and relationships of shoot yield, morphological and phenological traits in Chamomile populations (Anthemis triumfetti). J. Med. Plants By-products 4(1): 111-119.

Dadkhah A., Kafi M., Rasam G.H., 2009. The effect of planting date and plant density on growth traits, yield quality and quantity of Matricaria (Matricaria chamomilla). Iran. J. Hort. Sci. 23(2): 100-107.

Frank A.B., Sedives K.H., Hofman I., 1993. Determining grazing reading for native and tame pastures. North Dakota Univ. Ext. Serv. Bull., R-1061. N.D. Fargo implication. Proceedings of the Royal Society of Edinburgh 89: 45-58.

Hamisy M., Sefidkon F., Nasri M., Lebaschi M.H., 2012. Effects of different amounts of nitrogen, phosphor and bovine fertilizers on essential oil content and composition of Tanacetum parthenium. Iran. J. Med. Arom. Plants 28(3): 399-410.

Humphreys M.O., 1991. A genetic approach to the multivariate differentiation of perennial ryegrass (Lolium perenne L.) population. Heredity 66: $437-$ 443.

Golparvar A.R., Ghasemi-Pirbalouti A., 2011. Genetic improvement of essence percent and dry flower yield using indirect selection in German chamomile (Matricaria chamomilla L.). J. Herbal Drugs 1(4): 33-40.

IRMO, 2011. Information Provided by Local Metrological Station of Agriculture College of Karaj, University of Tehran, Iran.

Klimko M., Górski M., Czekalski P., Czarna A., 2006. Anthemis tinctoria L. (Asteraceae) in the Zielonka forest (the Wielkopolska region, Poland). Rocz. AR w Poznaniu CCCLXXVIII, Bot.-Stec. 10: 109-120.

Mozaffarian V., 2008. Flora of Iran, Asteraceae (Compositae): Tribes Anthemideae and Echinopeae. Institute of Forests and Rangelands Press, Tehran, Iran, Publication No. 59: 169.

Oberprieler C., Vogt R., 1999. Notes on some species of Anthemis (Compositae, Anthemideae) in Cyprus. Bocconea 11: 89-104. 
Pirkhezri M., Hassani M.E., Hadian S., 2010. Genetic diversity in different population of Matricaria chamomilla L. growing in southwest of Iran, based on morphological and RAPD markers. J. Med. Plants Res. 4(1): 1-13.

SAlAmon L., 1992. Production of chamomile, Chamomilla recutita (L.) Rauschert in Slovakia. J. Herbs Spices Med. Plants 1(2): 37-45.

SiddiQui M.H., OAD F.C., JMARO M.G.H., 2006. Emergence and nitrogen use efficiency of maize under different tillage operation and fertility levels. Asian J. Plant Sci. 5(3): 508-510.

Singh A., 1982. Cultivation of Matricaria chamomilla. In: Cultivation and Utilization of Aromatic Plants. A. Singh, C.K. Atal and B.M. Kapur (eds), RRL Jammu-Tawi: 653-657.
Solouki M.H., Mehdikhani H., Zeinali A., Emamjomeh A., 2008. Study of genetic diversity in Chamomile (Matricaria chamomilla) based on morphological traits and molecular markers. Sci. Hortic. 117(3): 281-287.

WARD J.H., 1963. Hierarchical grouping to optimize an objective function. J. Amer. Statist. Assoc. 58: 236244.

Uzel A., Guvensen A., Cetin E., 2004. Chemical composition and antimicrobial activity of the essential oils of Anthemis xylopoda O. Schwarz from Turkey. J. Ethnopharmacol. 95: 151-54.

Zargari A., 2008. Medicinal Plants. Tehran University Press, Tehran, Iran: 925.

Received May 20, 2016; accepted November 28, 2016 